\title{
A Study of Prevalence of Urinary Tract Infection among Children with Febrile Seizures in a Tertiary Care Hospital
}

\author{
${ }^{*}$ Dr.Punukollu Srinivas ${ }^{1}$, Dr.Snehalatha Gopu ${ }^{2}$, Dr.V.Murali Krishna ${ }^{3}$, \\ Dr.M.Arun Kumar. \\ ${ }^{I}$ Assistant professor of paediatrics, Niloufer hospital, Hyderabad, Telangana. \\ ${ }^{2}$ Assistant professor of paediatrics, Niloufer hospital, Hyderabad, Telangana. \\ ${ }^{3}$ Professor of paediatrics, Niloufer hospital, Hyderabad, Telangana. \\ ${ }^{4}$ Post graduate of paediatrics, Niloufer hospital, Telangana.
}

Corresponding author: *Dr.Snehalatha.Gopu ${ }^{2}$.H.NO10-4-771/7-1,satyasreearcade,sriramnagar colony, masabtank, Hyderabad, Telangana.500028

\begin{abstract}
Background: Febrile seizures and Urinary tract infection (UTI) are the two common morbidities in children which are extensively studied, with prevalence ranging from 2-5\% and 1-3\% respectively. However, there is paucity of studies combining both morbidities especially in India.

Objective: Primary objective of this study is to know the prevalence of Urinary tract infections in children with febrile seizures.

Methods: Study includes 100 children with febrile seizures in the age group of 6months to 5 years after excluding neurological and congenital abnormalities. Complete urine examination, urine culture sensitivity and ultrasound abdomen were done in children with suspected UTI.

Results: Mean age of presentation of febrile seizures is 34 months.89\% children had generalised seizures. 9\% cases had UTI with febrile seizures, $21.4 \%$ were infants.

Conclusion: Urinary tract infection is one of the major etiological cause for febrile seizure in children, more common in infants.
\end{abstract}

Keywords: children, febrile seizures, urinary tract infection.

\section{Introduction}

Febrile seizures are the most common type of seizures occurring in 2 to $5 \%$ of neurologically healthy children. Febrile seizures are to be differentiated from acute symptomatic seizures which are caused by intracranial infection or biochemical abnormalities (hypoglycaemia, hyponatremia, hypocalcaemia). Upper respiratory tract infection, gastroenteritis, UTI and viral exanthema are most often the cause of fever in children with febrile seizures. Fever is the most common manifestation of symptomatic UTI and sometimes it may be the only symptom of UTI. But in evaluation of children with febrile seizures, attention is not routinely paid to UTI.The frequency of fever in UTI is as follows: neonatal period- $11 \% ; 1-24$ months-38\%; $2-5$ years- $57 \%$. The frequency of seizure as a sign of UTI is as follows: neonatal period- $2 \% ; 1-24$ months- $7 \%$; 2-5 years-9\%. Thus, UTI should be considered in all cases of febrile seizures. Therefore, this study has been undertaken to determine the prevalence of UTI in children with febrile seizures.

\section{Aim \& objectives}

Primary objective of this study is to know the prevalence of urinary tract infection in children with febrile seizures and to study various etiological causes for febrile seizures.

\section{Methodology}

The data is collected from parents/guardians of children of age group 6 months to 5 years coming to Pediatric OP and Emergency Services Room of Niloufer Hospital with Febrile Seizures. It is an observationcross sectional study, is conducted over a period of one year from January 2015 to January 2016. The study included 100 children and it is a Non-randomized targeted sample. Included children with fever of more than $38^{\circ} \mathrm{C}$ and with both simple and complex febrile seizures. Children with intracranial infection, metabolic abnormalities, congenital anomalies and children received antibiotics $48 \mathrm{hrs}$ prior to admission were excluded. Complete urine examination, urine culture and ultrasound abdomen is done for suspected children with 
UTI.The data was analyzed on SPSS version 16 statistical analysis software. Data was analyzed with appropriate statistical tests at $5 \%$ level of significance.

\section{Results}

The mean age of presentation of febrile seizures was 34 months. In our study $37 \%$ cases were between $6-12$ months, $25 \%$ cases were in the age group of 1-2 years, $16 \%$ cases were belonging to $2-3$ years of age, $10 \%$ cases were between 3-4 years, $12 \%$ cases were in the age group of 4-5 years.58\% of children were males and $42 \%$ are females. $89 \%$ cases had generalized seizures and $11 \%$ cases had focal seizures.18\% had positive family history of febrile seizures. In $76 \%$ cases seizures lasted for less than five minutes and in $4 \%$ cases it lasted for more than 10 minutes. The mean temperature recorded was $101.8^{0} \mathrm{~F}$. Upper respiratory tract infection was found in $61 \%$ children, was the most common infective cause for febrile seizures in children. Urinary tract infection was seen in $9 \%$ cases. Other causes were pneumonia (13\%), dengue (11\%), chicken pox $(2 \%)$, measles $(1 \%)$, otitis media (1\%), abscess (1\%), and vaccination (1\%). In this study URTI $(61.9 \%)$ and UTI $(21.4 \%)$ were more common among children of age group 6-12 months as a cause for febrile seizure as compared to other age groups, pneumonia (33.3\%) was more common in the age group of 49-60months as a cause for febrile seizure, showing statistical significance in both age groups $(\mathrm{p}<0.05)$. various infections causing febrile seizures were given in table 1 .

Table1.Age wise distribution of cases

\begin{tabular}{|c|c|c|c|c|c|c|c|}
\hline \multicolumn{2}{|c|}{ Age group } & \multicolumn{5}{|l|}{ Diagnosis } & \multirow[t]{2}{*}{ Total } \\
\hline & & URTI & UTI & LRTI & Dengue & Others & \\
\hline $\begin{array}{l}06 \\
\text { months }\end{array}$ & -12 & $\begin{array}{l}26 \\
(61.9 \%)\end{array}$ & $\begin{array}{l}04 \\
(21.4 \%)\end{array}$ & $\begin{array}{l}03 \\
(07.1 \%)\end{array}$ & $\begin{array}{l}03 \\
(07.1 \%)\end{array}$ & $\begin{array}{l}01 \\
(02.4 \%)\end{array}$ & $\begin{array}{l}37 \\
(100 \%)\end{array}$ \\
\hline $\begin{array}{l}13 \\
\text { months }\end{array}$ & -24 & $\begin{array}{l}15 \\
(60.0 \%)\end{array}$ & $\begin{array}{l}03 \\
(12.0 \%)\end{array}$ & $\begin{array}{l}01 \\
(04.0 \%)\end{array}$ & $\begin{array}{l}03 \\
(12.0 \%)\end{array}$ & $\begin{array}{l}03 \\
(12.0 \%)\end{array}$ & $\begin{array}{l}25 \\
(100 \%)\end{array}$ \\
\hline $\begin{array}{l}25 \\
\text { months }\end{array}$ & -36 & $\begin{array}{l}07 \\
(43.7 \%)\end{array}$ & $\begin{array}{l}02 \\
(12.5 \%)\end{array}$ & $\begin{array}{l}02 \\
(12.5 \%)\end{array}$ & $\begin{array}{l}03 \\
(18.7 \%)\end{array}$ & $\begin{array}{l}02 \\
(12.5 \%)\end{array}$ & $\begin{array}{l}16 \\
(100 \%)\end{array}$ \\
\hline $\begin{array}{l}37 \\
\text { months }\end{array}$ & $\begin{array}{ll}- & 48 \\
\end{array}$ & $\begin{array}{l}06 \\
(60.0 \%) \\
\end{array}$ & 00 & $\begin{array}{l}03 \\
(30.0 \%) \\
\end{array}$ & $\begin{array}{l}01 \\
(10.0 \%)\end{array}$ & 00 & $\begin{array}{l}10 \\
(100 \%)\end{array}$ \\
\hline $\begin{array}{l}49 \\
\text { months }\end{array}$ & -60 & $\begin{array}{l}07 \\
(58.3 \%)\end{array}$ & 00 & $\begin{array}{l}04 \\
(33.3 \%)\end{array}$ & $01(8.3 \%)$ & 00 & $\begin{array}{l}12 \\
(100 \%)\end{array}$ \\
\hline Total & & $61(61 \%)$ & $09(09 \%)$ & $13(13 \%)$ & $11(11 \%)$ & $06(06 \%)$ & 100 \\
\hline
\end{tabular}

9\% children had positive urine microscopy. Among $9 \%$ children $66 \%$ had positive urine culture. E. coli $(50 \%)$ was the common pathogen found in urine culture. Other pathogens were enterobacteria, proteus, and citrobacter. All cases with UTI had abnormal ultrasound findings. Changes of cystitis (33\%) was common USG finding. Other findings were suggestive of bilateral hydroureteronephrosis (11\%), vesico ureteric reflex (11\%), and posterior urethral valves (11\%).

\section{Discussion}

The mean age of febrile seizure in present study is 34 months which is comparable to the other studies. Naveed-ur-Rehmann ET al ${ }^{(1)}$ found mean age was $22.97 \pm 9.52$ months. Nelson KB and Ellenberg et al ${ }^{(2)}$ found the average febrile seizure age to be 23.3 months. Amir Salari et al found average age of $39 \pm 15.92$ months. It is generally noted that the febrile seizures and the first febrile seizure are more common in second year. There was a preponderance of males in present study for the febrile seizure group. Incidence ratios of boys: girls have ranged from 1.1:1 to 2:1 (Nelson and Ellenberg ${ }^{(2)}$; Hauser and Forsgren et al). The majority of febrile seizures are simple seizures. In present study, simple febrile seizures constituted $89 \%$ of the seizures while $11 \%$ were focal seizures; Out of these $76 \%$ had duration of $<5 \mathrm{mins}, 20 \%$ had duration of $5-10 \mathrm{mins}$ and $4 \%$ had duration of $>15$ mins which was similar to Study by Livingston ${ }^{(3)}$ where majority (96.9\%) was simple febrile seizures. In present study family history is positive in $18 \%$ of children. While other studies by Farwell et al ${ }^{(4)}(29 \%)$ proved strong family history association, much greater than what reported by Lewis et al $(11 \%)$. Indar Sharawat et al ${ }^{(5)}$ found positive family history in $31.4 \%$. Similar studies done by Azhar S Daoud et al ${ }^{(6)}$ and Khalid $\mathrm{N}$ et al found family history of febrile seizures were not statistically significant.

Upper respiratory tract infection is the commonest trigger of febrile seizure in present group of children. Millichap et al ${ }^{(7)}$ (2006) found viral infections (URTI) as the common precipitating factor for febrile seizure. $62.4 \%$ children with febrile seizures had upper respiratory tract infections or flu or otitis media as per the study done by Nelson KB et al ${ }^{(8)}$. As per C T Deng et al ${ }^{(9)} 45.3 \%$ of children with febrile seizures had cough, 53.8\% children had coryza. Delpisheh et al ${ }^{(10)}$ found that common infections causing febrile seizures in children were Upper respiratory tract infections (42.3\%), gastroenteritis (21.5\%), otitis media (15.2\%), and pneumonia (8.7\%). Chevrie and Aicardi et al (1975) reported URTI in 72\% of the cases and Azhar S Daoud et 
al from Jordan, reported URTI as the commonest triggering factor, diagnosed in 53\% of cases, which is comparable to present study. However, the etiology of febrile seizures varies from country to country due to different infection profile.

In this study, UTI among children with febrile seizure was $9 \%$ and the result is comparable with the study done by Momen et al ${ }^{(11)}$ which showed $6.6 \%$ children with UTI had febrile seizures. LeeP et al ${ }^{(12)}$ found that $1.7 \%$ children with febrile seizures suffered from urinary tract infection, incidence is less compared to our study. 5\% frequency of urinary tract infections precipitating febrile seizures was found in children as per Bauchner $\mathrm{H}$ et al ${ }^{(13)}$. Among culture positive cases $50 \%$ grew E. coli and $11.11 \%$ each of proteus, citrobacter, entero species, which correlates with other studies. Bryan C. S et al ${ }^{(14)}$ reported E. coli as the common urinary pathogen in $85 \%$ of cases. According to Aravind Bagga et al ${ }^{(15)} 90 \%$ of first symptomatic urinary tract infection and $70 \%$ recurrent infections were due to E. coli. Hoberman et al ${ }^{(16)}$ (1993) reported as E. coli as the most common bacteria isolated in his study.

\section{Conclusion}

Urinary tract infection is one of the common etiological cause of fever in children, which precipitates febrile seizures and special consideration was given to infants with febrile seizures. Children with Febrile seizures should be screened for UTI by performing urine analysis and urine culture sensitivity tests. All children, who suffered from urinary tract infection, should be screened for congenital anomalies of urogenital tract to treat them as early as possible and to start chemoprophylaxis to prevent further episodes of infection and febrile seizures.

\section{References}

[1]. Naveed-ur-Rehman1, Billoo AG.Association between iron deficiency anaemia and febrile seizures. Coll Physicians Surg Pak. 2005 Jun; 15(6):338-40.

[2]. Nelson KB, Ellenberg JH. Predictors of epilepsy in children who have experienced febrile seizures. Engl J Med. 1976 Nov 4; 295(19):1029-33.

[3]. $\quad$ Livingston S, Pauli LL, Pruce I. Febrile seizures. Arch Neurol. 1979 Mar; 36(3):180.

[4]. Farwell JR, Lee YJ, Hirtz DG, et al. Phenobarbital for febrile seizures: effects on intelligence and on seizure recurrence. N Engl J Med. 1990; 322: 364-369.

[5]. Indar Sharawat et al. Evaluation of Risk Factors Associated with First Episode Febrile Seizure. Research gate February 2016, DOI: 10.7860/JCDR/2016/18635.7853.

[6]. Azhar S. Daoud et al. Iron Status: A Possible Risk Factor for the First Febrile Seizure. Epilepsia July 2002, DOI: 10.1046/j.15281157.2002 .32501

[7]. J. Gordon Millichap et al. Role of Viral Infections in the etiology of Febrile Seizures. j. Pediatrneurol 2006

[8]. Nelson KB, Ellenberg JH. Prognosis in children with febrile seizures. Paediatrics 1978; 61: 720-7.

[9]. C T Deng, H I Zulkifli. Febrile Seizures in Malaysian Children:Epidemiology and Clinical Features. Med J Malaysia Vol 49 No 4 Dec 1994.

[10]. Delpisheh, Yousef Veisani. Febrile Seizures: Etiology, Prevalence, and Geographical Variation. Iran J Child Neurol. 2014; 8(3): 30-37.

[11]. Momen A, Monajemzadeh SM. Frequency of Urinary Tract Infection among Children with Febrile Convulsion. Iranian Journal of Child Neurology. 2011; 1(1):29-31.

[12]. Lee P, Verrier Jones K. Urinary tract infection in febrile convulsions. Arch Dis Child. 1991;66(11):1287-90.

[13]. Bauchner H, Philipp B, Dashefsky B, Klein J. Prevalence of bacteriuria in febrile children.Pediatr Infect Dis J. 1987; 6(3):239-42.

[14]. Bryan CS, Reynolds KL. Community acquired bacteremic urinary tract infection: Epidemiology and Outcome. J Urol 1984; 132 : 490, 934.

[15]. Bagga A, Sharma J. Urinary tract infections clinical features, evaluation and treatment. Pediatr today 2000; 3: 395-401.

[16]. Hoberman A, Chao HP, Keller DM, Hickey R, Davis HW, Ellis D. Prevalence of urinary tract infection in febrile infants. J pediatr1993; 123: 17-23. 